\title{
EXPENSIVE AND CHEAP FUNDS - POLISH STOCK MUTUAL FUND FEES IN 2017
}

\author{
Alicja Fraś \\ Poznań University of Economics and Business, Poznań, Poland \\ e-mail: alicja.m.fras@gmail.com \\ ORCID: 0000-0003-1459-2492 \\ (C) 2018 Alicja Fraś \\ This is an open access article distributed under the Creative Commons Attribution-NonCommercial- \\ -NoDerivs license (http://creativecommons.org/licenses/by-nc-nd/3.0/)
}

DOI: 10.15611 fins.2018.4.03

JEL Classification: D53, G11, G23, C58

\begin{abstract}
Mutual fund fees are extraordinarily high in Poland - almost three times higher than in Western Europe and almost five times higher than in the United States. In fact is that from among 183 Polish open-ended stock mutual funds as many as 81 impose a management fee of $4 \%$, which is the highest value in the sample. The question arises whether it is really worth to invest in funds from the more expensive group. Comparing funds charging the highest fees (4\%) with the cheaper ones it seems that there is no statistically significant difference between rate of return, risk and efficiency. However, more expensive funds have on average higher costs, are three years older and have almost $70 \%$ bigger assets. This may suggest that a well-established market position - not performance - is the trigger for raising their fees. Interestingly, funds with a relatively high minimal initial contribution level $(5,000$ PLN) have significantly lower management fees with similar costs, total assets value and performance results. Further analysis has also indicated that the costs level (Total Expense Ratio) is higher for older funds, while it is not related to funds' size.
\end{abstract}

Keywords: mutual fund, performance, fees, charges.

\section{Introduction}

Economic laws and common sense both suggest that by paying more we either get better or more of the product. Nonetheless, some market or behavioral anomalies may suggest that this is not true. Some empirical studies imply that economic laws of price do not apply in the mutual funds market. In recent years the strong growth of index funds can be observed, managers' skills are being discussed and the obvious link between fund fees and performance has been undermined. However most of the studies fail to answer the question of why this anomaly occurs and what are its reasons.

In this study we tried to investigate what are the characteristics of the most expensive and the cheapest funds in Poland. First, we take a look at the performance 
and try to compare the risk, return and efficiency ratios for both groups. Then we dig deeper into other funds' features, such as fund age, net assets value, costs and minimal first contribution. The null hypothesis here is conservative - we believe that economic laws work and more expensive funds demonstrate better performance (higher rates of return and efficiency), while other factors are more or less the same for both groups. Looking at the fund management fees distribution we concluded that nearly half of the stock funds in the sample imposed a fee of $4 \%$. Next the funds imposing the $4 \%$ fee were compared with the group of cheaper funds using the Mann-Whitney test.

\section{Past research on mutual fund fees and performance}

The existing analyses on mutual fund performance, active management and fees may be divided in three categories. Some research reveals the lack of skill among active managers and in this way points at the inappropriately high fees when compared to the value added. Another kind of research indicates investors irrationality, which somehow explains why they still put their money in active funds even though they underperform compared to passive funds. The last group, and that appearing to be the most narrow, involves the studies directly exploring the fees level and its justification.

In 1995, Malkiel was one of the first who proved that stock mutual funds on average do not beat their benchmarks. His research covered the 20 -year time period of 1971 to 1991 on the US market. The finding was that previous reports on the attractiveness of active funds were biased because of survivorship bias [Malkiel 1995]. In 2010 the Nobel Prize winners, Fama and French, demonstrated with bootstrapping simulations that very few managers (less than 5\%) have the intrinsic skill to generate positive alpha and beat the benchmark after costs [Fama, Keneth, French 2010].

It has been repeatedly confirmed that active funds underscore passive and that managers very rarely have the skills to generate alpha, while charging fees not corresponding with their performance. Nonetheless, active funds still attract thousands of investors. Many scientists have tried to answer the question of whether there is some hidden sound reasons behind such behavior. One of the first who tried to explore this issue was Martin J. Gruber. He discovered that although capital is transferred to the funds with higher alpha ("New Money" has higher alpha than market average), there is still lot of money left in weakly performing funds. $\mathrm{He}$ concluded that this happens because of so-called "disadvantaged investors", who are less knowledgeable and do not seek top performers. Instead they follow their broker's advice or advertisements. Higher alpha of the flowing funds, when compared to the average can be explained by the fact that "sophisticated investors" are more sensitive and more likely to reallocate capital when the fund loses [Gruber 1996]. Researchers have also shown that although rates of return are not persistent 
[Carhart 1997], investors tend to follow the funds that demonstrated a good track record in the past [Sirri, Tufano 1998]. The existence of "disadvantaged investors" has been proved by Jain, $\mathrm{Wu}$ and Shuang Wu. They show that funds advertising their superior performance observe a $20 \%$ higher inflow compared to the control group. The same funds in the period after the advertised issue perform worse than average, but the investors naively believe that top returns are persistent [Jain, Shuang $\mathrm{Wu}$ 2000]. Another study pointing out some investors' behavior is that of de Guercio and Reuter from 2014. They say that funds choose only one of two possible distribution channels: intermediate or brokerage, so the segments are separate. Then they show how competition within these segments focuses around different fund features. For direct funds its all about alpha, while funds sold by brokers tend to maximize total rate of return, not alpha [Del Guercio, Reuter 2012]. A very recent paper by Cooper, Gulen and Rau discusses the issue of changing the fund's name. It seems that changing the fund's name to a "fashionable" one increases inflow by $28 \%$ without any portfolio change at all. A "fashionable" style is defined as a strategy that was successful in recent periods [Cooper, Gulen, Rau 2005].

In this paper we are going to focus rather on fund fees rather than their activeness. We take up the investors' perspective and analyse the simple rate of return, not the Carhart or Jensen alpha. Finally, the investor is interested in the money he or she receives from the investment after fees under a given risk level, disregarding the size of the funds, its target companies, the situation in the selected market sector or other factors. Even a loss in a declining market segment is still a loss. What finally counts is the return from investment, and the investor may conclude that funds investing in too big companies or poorly performing sectors may simply decrease the prices of its services, i.e. the fees. On the other hand, we also do not try to answer behavioral questions such as what are the reasons for the existence of expensive and badly performing funds and why do investors keep overpaying, as this is not the subject of this research and we lack data in that topic (like advertising, distribution channels or name change data). Firstly we want to answer the more general question of whether the anomalies and discrepancies from the economic theory exist. This may be an interesting extension of the conclusions of this research conclusions, however in this study we want to indicate the scale of market inefficiency in terms of fund fees allocation, and searching for its reasons would be the next step.

The area of fund fees is not as thoroughly explored as managerial skills or investors' rationality. Elton, Gruber and Blake in 2003 verified the superiority of the funds charging incentive fees when compared to those who do not. They proved that incentive fee funds not only achieve better alpha, but also have lower cost ratios. They attract inflows, however they also increase risk in tough periods [Elton, Gruber, Blake 2003]. The results of the study are interesting, however incentive fees in most cases are not the main component of the fund compensation. A wider study on fund fees has been performed by Gil-Bazo and Ruiz-Verdu. They analyzed the relation between fund fees and performance taking into account investors' demand 
elasticity. The relation between performance and fees turns out to be negative in the population. The authors explain that this phenomenon may appear as some investors represent strongly inflexible demand and are very unlikely to switch while the fund performs badly or fees rise. On the other side there are highly flexible, performance seeking investors, who expect high returns with the lowest costs.

The topic of fund fees in Poland is still largely unexplored. There are a few knowledgeable studies of mutual funds in general [Perez 2011, 2012]. In 2017, Fraś published a paper comparing the attractiveness of passive and active funds in Poland [Fraś, Rogowski 2016]. Although passive funds appear convenient, their fees remain a few times higher than in more highly developed countries, and provide a wide scope for further research. We greatly appreciate the approach of Gil-Bazo and Ruiz-Verdu, however we would like to put more emphasis on investor approach and fund profitability from his or her perspective. None of the previous studies have tried to describe the features of expensive funds and to figure out if the price of their services has any grounds and justification in its properties. If the answer here is positive, we can go further trying to explain the observed anomalies.

\section{Research methodology}

The data stems from Analizy Online [www.analizy.pl] website and the author's own data base of KIIDs (Key Investor Information Document). The sample covers 187 Polish open-ended and specialist open-ended mutual funds in 2012-2016.

The results of the most expensive funds in terms of management fee will be compared with the results of the cheaper ones. The initial data analysis has shown that almost half of the funds impose a management fee of $4 \%$, which is the highest in the sample (only one fund charges $4.25 \%$ ). Thus we can assume that funds charging $4 \%$ (or more) are the most expensive, and the rest are considered cheaper.

Then the performance of expensive and cheap funds was compared. The performance was measured with rates of return after fees (annualized average daily $\log$ rates), risk measured with standard deviations and efficiency measured with Sharpe ratios for 2012-2016. The Sharpe ratios were calculated as follows:

$$
\text { Sharpe ratio }=\frac{R_{x}-R_{f}}{\sigma_{x}},
$$

where $R_{x}$ is $\log$ daily rate of return of a given fund $x, \sigma_{x}$ is standard deviation of $\log$ daily rates of return of fund $x$ and $R_{f}$ is risk free rate, here $2.5 \%$ converted to log daily rate.

Then other characteristics of the funds were compared such as year of establishment, initial contribution limit (minimum), net assets and total expense ratio. All the mean comparisons were performed with the Mann-Whitney test and the $\mathrm{p}$-values are presented together with the sample means. The analysis of additional 
characteristics were performed on both sides - we measured the differences between fees and the other characteristic top and bottom quantiles. Thus we verified how fund characteristics change when comparing expensive and cheap, next comparing old and new, big and small, low and high-TER and finally, low and high initial contribution funds. In the end we take a broader look and check whether some of the differences are asymmetric, i.e. there is a difference in variable A between the top and bottom quantile of variable $\mathrm{B}$, but no difference in variable $\mathrm{B}$ between the top and bottom quantile of variable $A$.

\section{Results}

The histogram in Figure 1 indicates that fund management fees are focused around integers or their halves, with a very strong peak at $4 \%$ value.

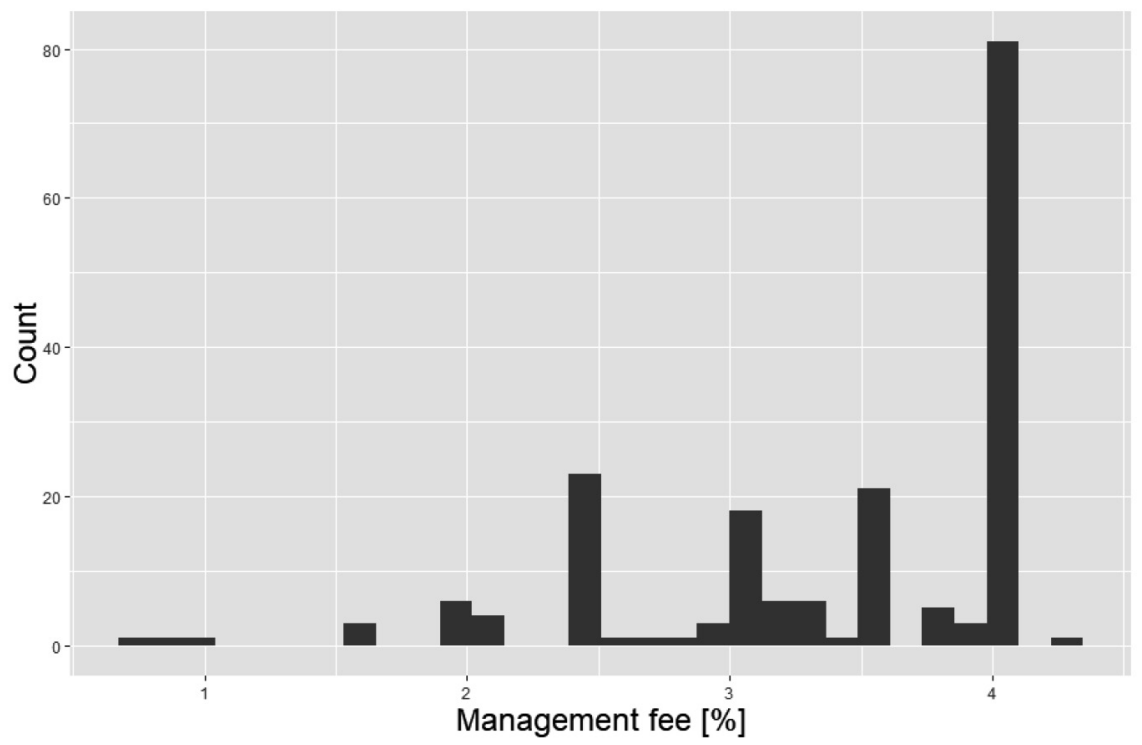

Fig. 1. Histogram of management fees of stock mutual funds in Poland in 2017

Source: Analizy Online, own calculations.

The results of the rate of return comparison are presented in Table 1. In almost all of the years (apart from 2014) the differences in means are not statistically significant (p-values above 0.05). In one case where the difference is significant (2014), it turns out to be much higher (almost 6 percentage points) for cheap funds.

Interestingly, sample means are in almost all the cases higher for cheaper funds than for the most expensive group. Then, if we could not confirm the superiority of top-charging funds in terms of returns, we may find their excellence in risk 
Table 1. Comparison of the rates of return of cheap and expensive funds in 2012-2016

\begin{tabular}{|c|c|c|c|}
\hline Year & $\begin{array}{c}\text { Sample mean } \\
\text { for cheap funds }\end{array}$ & $\begin{array}{c}\text { Sample mean } \\
\text { for expensive funds }\end{array}$ & $\begin{array}{c}\text { p-value } \\
\text { (Mann-Whitney test) }\end{array}$ \\
\hline 2012 & 31.8 & 26.9 & 0.33 \\
\hline 2013 & 15.8 & 16.8 & 0.82 \\
\hline 2014 & 3.8 & -2.1 & 0.01 \\
\hline 2015 & -4.5 & -6.3 & 0.26 \\
\hline 2016 & 13.9 & 11.4 & 0.43 \\
\hline
\end{tabular}

Source: Analizy Online, own calculations.

management (Table 2). However in the case of standard deviation, expensive funds also did no better. Apart from 2014, all the differences are statistically insignificant at $5 \%$ confidence level.

Table 2. Comparison of the standard deviations of cheap and expensive funds in 2012-2016

\begin{tabular}{|c|c|c|c|}
\hline Year & $\begin{array}{c}\text { Sample mean } \\
\text { for cheap funds }\end{array}$ & $\begin{array}{c}\text { Sample mean } \\
\text { for expensive funds }\end{array}$ & $\begin{array}{c}\text { p-value } \\
\text { (Mann-Whitney test) }\end{array}$ \\
\hline 2012 & 0.0079 & 0.0077 & 0.49 \\
\hline 2013 & 0.0085 & 0.0086 & 0.73 \\
\hline 2014 & 0.0083 & 0.0088 & 0.09 \\
\hline 2015 & 0.0099 & 0.0093 & 0.03 \\
\hline 2016 & 0.0092 & 0.0088 & 0.40 \\
\hline
\end{tabular}

Source: Analizy Online, own calculations.

The last performance measure to be verified is the efficiency (Table 3). Again, at $5 \%$ confidence level, apart from 2014, there are no significant differences. In conclusion, measuring the mean performance of cheap and expensive funds, we could not confirm the hypothesis that there is any superiority of top-charging funds, neither in terms of rate of return nor risk or efficiency.

Table 3. Comparison of the Sharpe ratios of cheap and expensive funds in 2012-2016

\begin{tabular}{|c|c|c|c|}
\hline Year & $\begin{array}{c}\text { Sample mean } \\
\text { for cheap funds }\end{array}$ & $\begin{array}{c}\text { Sample mean } \\
\text { for expensive funds }\end{array}$ & $\begin{array}{c}\text { p-value } \\
\text { (Mann-Whitney test) }\end{array}$ \\
\hline 2012 & 0.030 & 0.080 & 0.22 \\
\hline 2013 & 0.410 & 0.389 & 0.73 \\
\hline 2014 & 0.003 & -0.021 & 0.00 \\
\hline 2015 & -0.020 & -0.027 & 0.22 \\
\hline 2016 & 0.025 & 0.034 & 0.26 \\
\hline
\end{tabular}

Source: Analizy Online, own calculations. 
The data does not support the hypothesis that there are significant differences in performance between cheap and expensive funds. Then we also verified other non-performance related factors that may be associated with imposing higher management fees (Table 4). The factors verified are fund age, total net assets, total expense ratio and minimal initial contribution to the fund.

Table 4. Comparison of other factors of cheap and expensive funds in 2016

\begin{tabular}{|l|c|c|c|}
\hline \multicolumn{1}{|c|}{ Factor } & $\begin{array}{c}\text { Sample mean } \\
\text { for cheap funds }\end{array}$ & $\begin{array}{c}\text { Sample mean } \\
\text { for expensive funds }\end{array}$ & $\begin{array}{c}\text { p-value } \\
\text { (Mann-Whitney test) }\end{array}$ \\
\hline Year of establishment & 2010 & 2007 & 0.00 \\
\hline Total net assets & 109.2 & 181.6 & 0.00 \\
\hline TER & 3.09 & 4.27 & 0.00 \\
\hline Minimal initial contribution & 28,233 & 2,793 & 0.00 \\
\hline
\end{tabular}

Source: Analizy Online, own calculations.

Cheap and expensive funds differ in all the examined areas. Cheap funds are both smaller and younger. This suggests that some funds can impose higher fees because of their established position on the market. Expensive funds also incur much higher costs. This might be due to higher management expenses, however the data on performance differences does not support that. So either these funds do not bear high management costs, or their investment in management is inefficient, as it is not reflected in fund performance. It is more likely that these funds have higher distribution and advertisement costs. Cheap funds also tend to have a much higher initial contribution level. The sample mean is over ten times higher in the case of cheap funds, and the difference is very strong and highly significant. Let us look closer at the low and high contribution funds (Table 5).

Table 5. Comparison of other factors of low (below 5,000 PLN) and high (over 5,000 PLN) initial contribution funds in 2016

\begin{tabular}{|l|c|c|c|}
\hline \multicolumn{1}{|c|}{ Factor } & $\begin{array}{c}\text { Sample mean } \\
\text { for high contr. funds }\end{array}$ & $\begin{array}{c}\text { Sample mean } \\
\text { for low contr. funds }\end{array}$ & $\begin{array}{c}\text { p-value } \\
\text { (Mann-Whitney test) }\end{array}$ \\
\hline Year of establishment & 2011 & 2009 & 0.11 \\
\hline Total net assets & 171.9 & 137.5 & 0.32 \\
\hline TER & 3.63 & 3.60 & 0.70 \\
\hline Management fee & 2.93 & 3.43 & 0.01 \\
\hline
\end{tabular}

Source: Analizy Online, own calculations.

The data from Table 5 indicates that low and high contribution funds do not differ in terms of age, assets or costs. They only charge less, while not displaying the characteristics of the most expensive funds (bigger assets, age). Additional tests 
also did not confirm the hypothesis that their performance is worse. To conclude, investing in funds with a high initial contribution level may be a good choice, as these funds - while maintaining a similar level of performance - offer much lower fees $(1.5 \%$ in our sample). We also analyzed other factors in this way, such as age, total assets and TER. The division line between these groups was sample mean (funds with age, assets and TER below and above average).

Table 6. Comparison of other factors of old and new funds in 2016

\begin{tabular}{|l|c|c|c|}
\hline \multicolumn{1}{|c|}{ Factor } & $\begin{array}{c}\text { Sample mean } \\
\text { for new funds }\end{array}$ & $\begin{array}{c}\text { Sample mean } \\
\text { for old funds }\end{array}$ & $\begin{array}{c}\text { p-value } \\
\text { (Mann-Whitney test) }\end{array}$ \\
\hline Management fee & 3.16 & 3.63 & 0.00 \\
\hline Total net assets & 72.94 & 219.96 & 0.00 \\
\hline TER & 3.39 & 3.87 & 0.00 \\
\hline Minimal initial contribution & 8,984 & 26,790 & 0.37 \\
\hline
\end{tabular}

Source: Analizy Online, own calculations.

Older funds differ in all the aspects apart from initial contribution level. They are both bigger, more expensive and have higher TER (Table 6).

Table 7. Comparison of other factors of low (below mean of 3.6\%) and high TER funds in 2016

\begin{tabular}{|l|c|c|c|}
\hline \multicolumn{1}{|c|}{ Factor } & $\begin{array}{c}\text { Sample mean } \\
\text { for high-TER funds }\end{array}$ & $\begin{array}{c}\text { Sample mean } \\
\text { for low-TER funds }\end{array}$ & $\begin{array}{c}\text { p-value } \\
\text { (Mann-Whitney test) }\end{array}$ \\
\hline Year of establishment & 2008 & 2011 & 0.00 \\
\hline Total net assets & 132.1 & 159.2 & 0.11 \\
\hline Management fee & 3.77 & 2.82 & 0.00 \\
\hline Minimal initial contribution & 4,964 & 34,741 & 0.26 \\
\hline
\end{tabular}

Source: Analizy Online, own calculations.

Funds with high and low cost levels are described in Table 7. These funds differ in terms of year of establishment and management fee. However costly funds do not vary significantly in terms of total assets or minimal initial contribution. The lack of relation between size of the funds can be confirmed by the outcomes of the analysis of large and small funds (Table 8). The p-value is very high, which suggests the lack of significant differences. However big funds are older, which seems natural, and also impose higher fees, although not reflected in the higher total expense ratio. Minimal contribution differs in the sample means, however the difference is not statistically significant.

Finally, it may be easier to take a more general look at the outcomes. We gathered the data to see whether some dependencies are asymmetric, i.e. there is a difference between the top and bottom quantiles of variable A when comparing to variable B, 
Table 8. Comparison of other factors of big and small funds in 2016

\begin{tabular}{|l|c|c|c|}
\hline \multicolumn{1}{|c|}{ Factor } & $\begin{array}{c}\text { Sample mean } \\
\text { for big funds }\end{array}$ & $\begin{array}{c}\text { Sample mean } \\
\text { for small funds }\end{array}$ & $\begin{array}{c}\text { p-value } \\
\text { (Mann-Whitney test) }\end{array}$ \\
\hline Year of establishment & 2006 & 2011 & 0.00 \\
\hline Management fee & 3.61 & 3.28 & 0.01 \\
\hline TER & 3.58 & 3.66 & 0.97 \\
\hline Minimal initial contribution & 38,598 & 8,594 & 0.60 \\
\hline
\end{tabular}

Source: Analizy Online, own calculations.

but no difference between the quantiles of variable B when comparing the values of A. Figure 2 presents the relative size of the difference and it's statistical significance. The colors of the tiles represent the percentage growth of the X-axis variable, when moving from the bottom to the top quantile of variable Y. Statistically significant outcomes (at 1\% level) are marked with black dots.

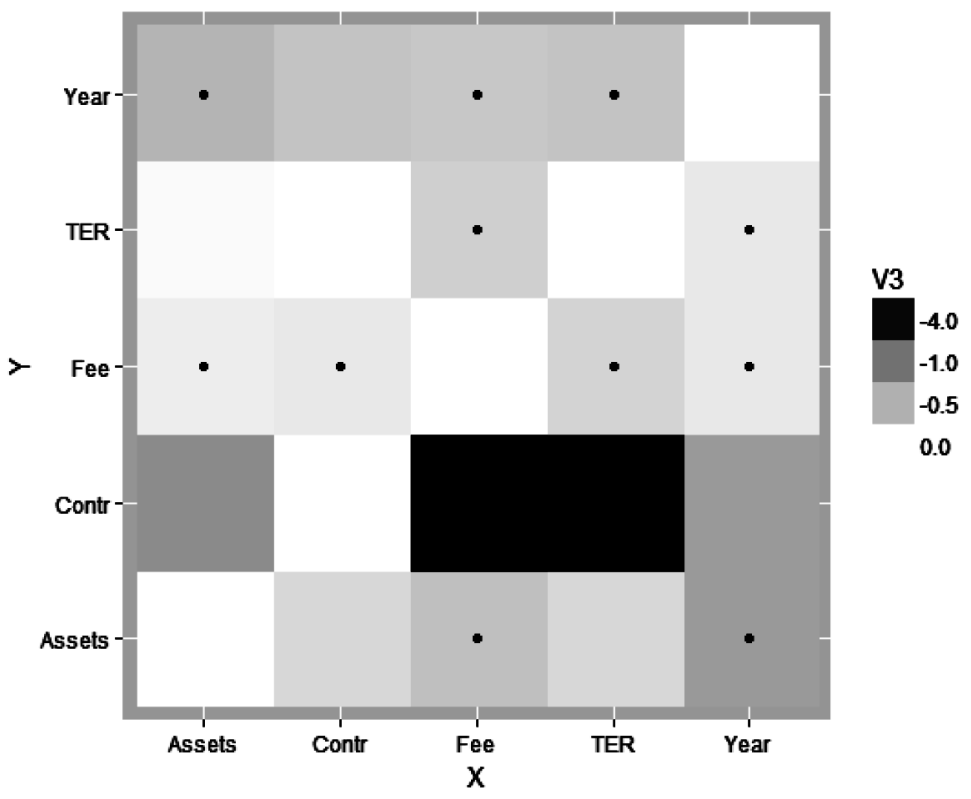

Fig. 2. Matrix of dependency and significance of differences between top and bottom quantiles of mutual fund traits

Source: Analizy Online, own calculations.

The whiter the tile, the more positive is the relation, while the darker the tile, the more negative. In terms of statistical significance the matrix is symmetric under the diagonal. This suggests that the diagonal is white (as the relation here is $100 \%$ 
positive), but we do not mark it as significant as these outcomes are not significant in the sense of reasoning.

What is interesting here is that cheap and expensive funds differ in all areas. Older funds have higher costs, are more expensive and bigger. Big funds, although not differing in terms of costs, are more expensive and older. The sample mean of TER was slightly higher for small funds, while the fees are significantly lower $(0.33$ percentage points). A minimal contribution level is not associated with any of the other factors apart from the management fee - with all the other factors (including performance) kept the same, the investor can decrease the fee paid significantly by just choosing the high-contribution limit fund.

\section{Conclusions}

The main assumption of the research was that more expensive funds bring more value to the customer, i.e. demonstrate better performance in terms of rates of return, risk and efficiency. Thus there is some rational incentive to overpay. We had to reject this hypothesis as all the compared performance measures in all the years covered were statistically insignificant. Then we verified other factors as potential differentiators between expensive and cheap funds. In this case all the measured factors were significant. Cheaper funds are on average three years younger than expensive ones, they are also over one-third smaller, cost efficient in terms of total expense ratio (lower by 1.2 percentage points) and have a higher average initial contribution level. Thus the conclusion here is that funds raise their fees not based on top performance, but rather considering other factors. The significance of fund's age and total net assets suggests that this may be due to the reputation and goodwill factor. We can also assume that the increased costs (TER) for these funds are also associated with higher advertising and distribution expenses.

Minimal initial contribution is not a typical factor in funds' analysis, however it turned out to be very significant. Only a small fraction of the funds in the sample demanded an initial contribution above 5,000 PLN (around 10\%). However, even such a low cut-off point allowed us to indicate significant differences between the funds. Those with a higher initial contribution demonstrated much better results. When looking closer at the data, we find that there are no differences in any other dimension (performance, age, assets or costs). Funds with a higher initial contribution are simply cheaper, with all other characteristics unchanged. A look at the names of the funds in the sample allows for the conclusion that most of these funds contain words like "premium" or "prestige" in their names. These are probably high-end products for premium customers. In trying to attract investors, these funds offer lower fees for more affluent clients.

We also took a closer look at the other factors mentioned. Younger funds are in general much smaller, a bit cheaper and a bit more cost-efficient than the old ones. The differences in contribution level are not statistically significant. All that is not 
surprising - it takes time for new funds to grow in assets, gain reputation and start discounting its increasing fees. Cost efficient funds appear both among big and small funds (the differences in fund assets are not significant). However low-TER funds are younger and offer lower management fees. This suggests that increasing expenses goes with fund's age rather than with the assets level. Finally, large funds tend to be older - funds bigger than average are five years older than the smaller ones. They are also slightly cheaper ( 0.33 percentage points), but not less cost-efficient.

The most interesting outcome of this study is the fact that funds do not leverage their past performance when setting up their fees scheme. What they do instead, is look at funds' age and assets level. This suggests that a well-known name and recognizability means more than just better performance. Further research would help to answer the questions and validate the results of the present study. It could be suggested to test also the current fees, broader than the management fee and captures most of the costs imposed by the funds. Broadening the time horizon and adding international comparisons would also strengthen the basis of the reasoning. The research outcomes also raise the question of why Polish investors do not put their money into cheaper foreign investment funds. This issue was not the topic of the present paper, however the potentially strong position of Polish funds may come from low market maturity and accessibility to international funds, poor investors' awareness and reluctance towards currency risk. Nonetheless, this hypothesis shall be also explored in further research.

\section{Bibliography}

Carhart M.M. 1997, On persistence in mutual fund performance, The Journal of Finance, 52(1), p. 57.

Cooper M.J., Gulen H., Rau P.R., 2005, Changing names with style: Mutual fund name changes and their effects on fund flows, Journal of Finance, 60(6), pp. 2825-2858.

Del Guercio, D., Reuter J., 2012, Mutual fund performance and the inventive to generate alpha, Journal of Finance, 69(4), pp. 1673-1704.

Elton E.J., Gruber M.J., Blake Ch.R., 2003, Incentive fees and mutual funds, Journal of Finance, 58(2), pp. 779-804.

Fama E.F., French K.R., 2010, Luck versus skill in the cross-section of mutual fund returns, Journal of Finance, 65(5), pp. 1915-1947.

Fraś A., Rogowski W., 2016, The attractiveness of passive forms of investment in Poland, Journal of Management and Financial Sciences, 9(25).

Gruber M.J., 1996, Another puzzle: The growth in actively managed mutual funds, Journal of Finance, 51(3), pp. 783-810.

Jain P.C., Shuang Wu J., 2000, Truth in mutual fund advertising: Evidence on future performance and fund flows, Journal of Finance 55(2), pp. 937-958.

Malkiel B., 1995, Returns from investing in equity mutual funds 1971 to 1991, The Journal of Finance, vol. 50 , no. 2.

Perez K., 2011, Fundusze inwestycyjne, Materiały dydaktyczne, Wydawnictwo Uniwersytetu Ekonomicznego w Poznaniu, Poznań. 
Perez K., 2012, Efektywność funduszy inwestycyjnych. Podejście techniczne i fundamentalne, Wydawnictwo Difin, Warszawa.

Sirri E.R., Tufano P., 1998, costly search and mutual fund flows, The Journal of Finance, 53(5), pp. 1589-1622.

\section{DROGIE I TANIE FUNDUSZE - OPLATY W POLSKICH FUNDUSZACH AKCJI W 2017 ROKU}

Streszczenie: Poziom opłat w Polsce jest niezwykle wysoki - prawie trzykrotnie wyższy niż w Europie Zachodniej oraz niemal pięciokrotnie wyższy niż w USA. Okazuje się, że spośród 183 polskich otwartych funduszy akcji aż 81 pobiera opłatę w wysokości 4\%, czyli najwyższą obserwowaną w próbie. Nasuwa się pytanie, czy warto inwestować w fundusze $\mathrm{z}$ grupy najdroższych. Porównując fundusze o najwyższych opłatach za zarządzanie (4\%) z tańszymi, możemy zaobserwować, że nie ma między nimi statystycznie istotnych różnic na poziomie zarówno stóp zwrotu, ryzyka, jak i efektywności. Niemniej jednak droższe fundusze mają istotnie wyższy poziom kosztów oraz są średnio o 3 lata starsze i mają o prawie o $70 \%$ większe aktywa, co może sugerować, że ugruntowana pozycja na rynku zachęca do podnoszenia cen. Co ciekawe, fundusze o relatywnie wysokich dolnych limitach wpłat (5000 zł) mają istotnie niższe opłaty za zarządzanie przy zbliżonym poziomie kosztów, wielkości aktywów i wynikach. Dalsza analiza wykazała również, że poziom kosztów (TER) jest wyższy dla starszych funduszy, natomiast nie ma na niego wpływu ich wielkość.

Słowa kluczowe: fundusz inwestycyjny, wyniki, opłaty. 